gow, and the Royal Maternity Hospital, Glasgow, for their participation in this study.

\section{References}

${ }^{1}$ Hellström, K E, Hellström, I, and Brawn, J, Nature, 1969, 224, 914.

2 Youtananukorn, V, and Matangkasombut, P, Clinical and Experimental Immunology, 1972, 11, 549.

${ }^{3}$ Maroni, E S, and Parrot, D M V, Clinical and Experimental Immunology, 1973, 13, 253.
4 Stevenson, A C, et al, Lancet, 1971. 2, 1286.

5 Petrucco, O M, et al, British Medical fournal, 1974, 1, 473.

6 Tribe, C R, Smart, G E, and MacKenzie, J C, British Medical fournal, 1974, 2, 335.

7 Laurell, C B, Analytical Biochemistry, 1965, 10, 358.

${ }^{8}$ Mayer, $\mathrm{M}$ M, in Experimental Immunochemistry, ed E A Kabat and M M Mayer, p 133. Springfield, Illinois, Thomas, 1961.

${ }^{9}$ Horne, C H W, et al, Clinical and Experimental Immunology, 1973, 13, 603.

10 Thompson, R, British Medical fournal, 1974, 2, 60.

11 Horne, C H W, Howie, P W, and Goudie, R B, Fournal of Clinical Pathology, 1970, 23, 514.

12 Kitzmiller, J L, et al, American fournal of Obstetrics and Gynecology, 1973, $117,312$.

\title{
Standardised approach to gluten challenge in diagnosing childhood coeliac disease
}

\author{
CHRISTOPHER J ROLLES, ALEXANDER S MCNEISH
}

British Medical fournal, 1976, 1, 1309-1311

\section{Summary}

Thirty-five children, in whom coeliac disease had been diagnosed on inadequate grounds and who had been on a gluten-free diet for one to 10 years, were challenged with gluten in accordance with a standardised procedure.

All children were admitted to hospital for 48 hours for general assessment, two one-hour blood xylose tests, and the introduction of gluten. Thirty children underwent a pre-challenge peroral jejunal mucosal biopsy; the specimens were either normal or showed slight nonspecific abnormalities. Gluten powder $20 \mathrm{~g} /$ day was given in addition to an otherwise gluten-free diet. The children were reassessed as outpatients every two weeks, when a one-hour blood xylose test was performed. Repeat biopsy was performed when xylose absorption fell or after three months.

Seventeen children had abnormal post-challenge biopsy appearances compatible with coeliac disease in relapse; 14 of these children completed their challenge within eight weeks. Seventeen children had completely normal biopsy appearances at the end of three months and were returned to a normal diet. One to two years later eight underwent repeat biopsies, which showed nothing abnormal. In only one child, the oldest in the series, were the histological findings equivocal.

In the $\mathbf{1 7}$ children in whom coeliac disease was confirmed the duration of gluten challenge was not related to age, duration of gluten-free diet, histological findings on the pre-challenge biopsy, or HLA status.

\section{Introduction}

Many children are still diagnosed as having coeliac disease on inadequate criteria, often without a jejunal biopsy. Answers to a questionnaire sent out by the Coeliac Society in $1972^{1}$ indicated that under half the children diagnosed under the age of five who

Institute of Child Health, University of Birmingham, Birmingham B16 8ET

CHRISTOPHER J ROLLES, BSC, MRCP, lecturer in child health ALEXANDER S MCNEISH, MSC, MRCP, senior lecturer in child health became affiliated to the society that year had had a jejunal biopsy. Clinical diagnosis can never be completely accurate ${ }^{2}$ and strict diagnostic criteria demand at least histological proof of a severe enteropathy and evidence that this was caused by gluten. ${ }^{3}$

A gluten challenge presents two main practical problems. Firstly, if a normal diet is used the amount of gluten taken is unknown and children who have been on a gluten-free diet for some time may be resistant to eating gluten-containing foods. Secondly, there may be difficulty in deciding when to take a post-challenge intestinal biopsy.

Some workers have attempted to control the gluten challenge by giving known amounts of gluten-containing foods ${ }^{4}$ or by giving measured extracted gluten in addition to a gluten-free diet. ${ }^{5}$ In a recent study Packer et $a l^{6}$ gave $10 \mathrm{~g}$ of gluten a day for three months and then performed a biopsy. We have used $20 \mathrm{~g} /$ day to confirm coeliac disease in children diagnosed in infancy ${ }^{7}$; we used a fall in xylose absorption to determine the timing of the post-challenge biopsy.

In this study we attempted to apply similar methods to older children who had been on a gluten-free diet for over a year and who would therefore be expected to have normal small-bowel histology. Our object was to obtain definitive proof of glutensensitive enteropathy in the shortest time with a minimum of discomfort.

\section{Patients and methods}

Thirty-five children ( 15 boys) diagnosed as having coeliac disease on inadequate criteria were investigated. Five of these had been diagnosed under the age of 1 year with a jejunal biopsy and have been described elsewhere. ${ }^{7}$ The others had all been diagnosed on clinical and biochemical grounds alone. The children's ages ranged from $1 \frac{1}{2}$ to 15 years (mean $5 \cdot 7$ years) and they had been on gluten-free diets for one to 10 years (mean $4 \cdot 2$ years).

\section{CHALLENGE PROTOCOI}

All children were admitted to hospital for $\mathbf{4 8}$ hours. Each underwent two baseline one-hour blood xylose tests. Thirty had a pre-challenge intestinal biopsy specimen taken from the ligament of Treitz, and in 22 the HLA status was determined. Commercial gluten powder (Energen Foods Ltd), $10 \mathrm{~g}$ twice daily, was added to an otherwise strict gluten-free diet. Outpatient clinical examinations were made every two weeks and the blood xylose test was repeated. An intestinal bionsy was to be performed when $(a)$ there was a confirmed fall in blood xylose concentrations from normal $(\geqslant 1.33 \mathrm{mmol} / 1(20 \mathrm{mg} / 100$ $\mathrm{ml})$ ) to abnormal $(<1.33 \mathrm{mmol} / \mathrm{l})^{8} ;(b)$ serious symptoms attributable 
to gluten occurred; or $(c)$ neither $a$ nor $b$ occurred but three months of gluten challenge had been completed. In practice no biopsies were performed for reason $b$. If the repeat biopsy specimen was clearly abnormal the diagnosis of coeliac disease was regarded as confirmed. Those children who had normal histological appearances after three months of gluten ingestion were returned to a normal diet and reviewed regularly.

Powdered commercial gluten is not very palatable. Parents were instructed to give it either whisked with flavoured milk or sprinkled on gluten-free breakfast cereal. Three children objected to it so strongly that Energen wheat flakes were substituted (23-25 g of flakes contain $10-11 \mathrm{~g}$ of gluten).

\section{Results}

Results are shown in the table.

Small-bowel histology-Thirty children underwent pre-challenge biopsies. Twenty-six showed normal small-bowel histology and four showed slight non-specific abnormalities. All 35 children underwent biopsy at the end of the challenge. Seventeen (group 1) had total villous atrophy, 17 (group 2) had normal appearances, and one child (case 18) had equivocal biopsy findings-fused stunted villi with moderate infiltration in the lamina propria.

Duration of challenge-In group 1, using the fall in one-hour blood xylose concentration as an indication for repeat biopsy, challenge was completed within eight weeks in 14 children. Sixteen of the group 2 children were challenged for a full 12 weeks and one for just over 11 weeks. Cases 19, 26, and 29 showed a fall in one-hour blood xylose at some stage during the 12 weeks; this was not subsequently confirmed, so the challenge was continued. Eight of the children in this group had a further biopsy while on a normal diet one to two years after the end of the challenge, and appearances were all normal.

Symptoms during challenge-Four children in group 1 had mild symptoms, anorexia and abdominal discomfort, at some stage. Three children in group 2 had similar symptoms and a further three had slightly more severe symptoms, including headaches and dizziness, but in no case was termination of challenge necessary. No child in either group had significant diarrhoea or weight loss.

HLA status-Ten out of $12(83 \%)$ children in group 1, and two out of nine in group $2(22 \%)$ were HLA-8.

Case 18-This 15-year-old girl was the oldest studied. She had been diagnosed as having coeliac disease on clinical grounds at the age of 3 and since then had been in various residential schools because of her condition. The pre-challenge biopsy gave normal results and her pre-challenge one-hour blood xylose test gave a result at the lower limit of normal. The results of review blood xylose tests fluctuated within a small range below the dividing line between normal and abnormal. Because of past difficulties encountered with the one-hour blood xylose test in adolescents her challenge was continued for eight weeks, after which a repeat biopsy showed a moderately severe enteropathy but not the classical flat appearances of coeliac disease. She was therefore placed on a normal diet and a biopsy one year later showed normal appearances.

\section{Discussion}

Our standardised procedure made it possible to confirm the diagnosis of coeliac disease in 17 children within three months. The dose of gluten used in the study ( $20 \mathrm{~g} /$ day) was twice that used by Packer et $a l^{5}$ but it did not produce more adverse symptoms. The speed of relapse of treated patients may be partly dose related, ${ }^{9}$ so that a relatively large dose of gluten may shorten the period of challenge. The addition of powdered gluten to an otherwise gluten-free diet avoids the need to taste "forbidden fruits."

The practical problem in gluten challenges of knowing when to perform an intestinal biopsy was solved for us in the present investigation because a confirmed fall in the blood xylose

Details of patients and investigations. Cases 1-17 formed group 1 and cases 19-35 formed group 2

\begin{tabular}{|c|c|c|c|c|c|c|c|c|c|c|}
\hline \multirow{2}{*}{$\begin{array}{l}\text { Case } \\
\text { No }\end{array}$} & \multirow{2}{*}{$\begin{array}{l}\text { Sex and } \\
\text { age }\end{array}$} & \multirow{2}{*}{$\begin{array}{l}\text { Duration } \\
\text { of gluten- } \\
\text { free diet } \\
\text { (years) }\end{array}$} & \multirow[b]{2}{*}{ HLA } & \multirow[b]{2}{*}{$\begin{array}{c}\text { Pre- } \\
\text { challenge } \\
\text { biopsy* }\end{array}$} & \multicolumn{2}{|r|}{ 1-h Blood xylose (mmol/1) } & \multirow{2}{*}{$\begin{array}{c}\text { Duration } \\
\text { of } \\
\text { challenge } \\
\text { (weeks) }\end{array}$} & \multirow{2}{*}{$\begin{array}{c}\text { Post- } \\
\text { challenge } \\
\text { biopsy }\end{array}$} & \multirow{2}{*}{$\begin{array}{c}\text { Symp- } \\
\text { toms } \\
\text { during } \dagger \\
\text { challenge }\end{array}$} & \multirow[b]{2}{*}{ Clinical follow-up $\ddagger$} \\
\hline & & & & & $\begin{array}{l}\text { Initial } \\
\text { value }\end{array}$ & $\begin{array}{l}\text { Values during challenge } \\
\text { (week of test) }\end{array}$ & & & & \\
\hline $\begin{array}{r}1 \\
2 \\
3 \\
4 \\
5 \\
6 \\
7 \\
8 \\
9 \\
10 \\
11 \\
12 \\
13 \\
14 \\
15 \\
16 \\
17\end{array}$ & $\begin{array}{lr}M & 7 \\
M & 2 \\
F & 2 \\
F & 4 \frac{1}{2} \\
F & 8 \\
M & 10 \frac{1}{2} \\
\text { F } & 8 \\
M & 7 \\
F & 12 \\
M & 7 \\
M & 10 \\
F & 4 \\
F & 2 \frac{1}{2} \\
F & 5 \frac{1}{2} \\
M & 4 \\
F & 9 \\
F & 6\end{array}$ & $\begin{array}{c}6 \\
1 \\
1 \\
4 \\
5 \frac{1}{2} \\
10 \\
6 \frac{1}{2} \\
4 \\
10 \\
5 \frac{1}{2} \\
9 \\
3 \\
1 \frac{1}{2} \\
5 \\
3 \frac{1}{2} \\
7 \\
3\end{array}$ & $\begin{array}{l}1,5,8 \\
10, W 17 \\
1,9,8, W 5 \\
1,5,8 \\
1,3,7,8 \\
1,8,12 \\
1,11,8 \text {, W } 5\end{array}$ & $\begin{array}{l}+ \\
+ \\
+ \\
+ \\
+ \\
+ \\
+ \\
+ \\
+ \\
+ \\
+ \\
+ \\
+ \\
+ \\
+ \\
+\end{array}$ & $\begin{array}{l}2.13 \\
2.06 \\
2.53 \\
2.40 \\
2.20 \\
1.67 \\
2.69 \\
2.69 \\
1.33 \\
2.53 \\
1.27 \\
2.53 \\
2.73 \\
2.80 \\
1.67 \\
1.73 \\
1.80\end{array}$ & $\begin{array}{l}0.20(2), 0.53(4) \\
1.20(2), 0.93(4) \\
0.60(4), 0.73(4) \\
1.07(2), 0.67(6) \\
0.60(4), 0.67(4), 0.80(6) \\
1.60(2), 2.26(4) \\
1.53(2), 0.73(4), 0.73(6) \\
1.86(4), 0.87(6) \\
1.00(2), 0.47(4), 0.87(6) \\
1.53(2), 1.27(4), 1.00(6) \\
0.67(4), 0.13(6) \\
2.46(4), 1.40(6), 0.80(8) \\
1.67(2), 1.07(6), 0.87(8) \\
1.47(2), 1.67(4), 1.07(6), 0.53(8) \\
1.53(2), 1.07(4), 0.53(6), 0.87(8) \\
2.26(2), 2.06(4), 2.00(6), 1.07(8), 0.80(10) \\
1.26(2), 1.86(6), 2.13(8), 1.60(10), 1.27(12), 0.73(13)\end{array}$ & $\begin{array}{r}4 \\
4 \\
5 \\
5 \\
6 \\
6 \\
6 \\
6 \\
7 \\
8 \\
8 \\
8 \\
8 \\
8 \\
9 \\
12 \\
13\end{array}$ & 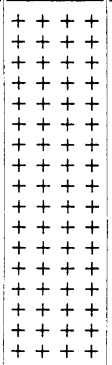 & $\begin{array}{l} \pm \\
\pm \\
\pm \\
= \\
= \\
= \\
\pm \\
\pm \\
\pm \\
\pm \\
\pm \\
\pm \\
-\end{array}$ & Well on gluten-free diet \\
\hline 18 & F 15 & 12 & $1,2, W 15$ & + & 1.53 & $1.07(2), 1.27(4), 0.73(6), 2.00(8)$ & 8 & +++ & - & $\begin{array}{l}\text { Normal diet, :epeat } \\
\text { biopsy } 12 \text { mo normal }\end{array}$ \\
\hline 19 & F 10 & 8 & $2,9,7, w 18$ & + & $1 \cdot 73$ & $1.47(2), 3.13(4), 1.07(6), 1.80(8), 1.00(10), 2.00(12)$ & 12 & + & + & $\begin{array}{l}\text { Normal diet, repeat } \\
\text { biopsy } 12 \text { mo normal }\end{array}$ \\
\hline $\begin{array}{l}20 \\
21\end{array}$ & $\begin{array}{ll}M & 6 \\
F & 4 \frac{1}{2}\end{array}$ & $\begin{array}{l}5 \\
3 \frac{1}{2}\end{array}$ & $\begin{array}{l}2,12, \mathrm{~W} 27 \\
1,2, \mathrm{~W} 10, \mathrm{~W} 17\end{array}$ & + & $\begin{array}{l}1 \cdot 80 \\
2 \cdot 26\end{array}$ & $\begin{array}{l}1.60(2), 2.06(4), 1.47(6), 1.33(8), 1.40(12) \\
2.00(2), 1.67(4), 1.60(6), 1.33(8), 1.73(10), 1.80(12)\end{array}$ & $\begin{array}{l}12 \\
12\end{array}$ & + & \pm & $\begin{array}{l}\text { Normal diet } \\
\text { Normal diet, repeat } \\
\text { biopsy } 18 \text { mo normal }\end{array}$ \\
\hline $\begin{array}{l}22 \\
23 \\
24\end{array}$ & $\begin{array}{ll}\mathrm{F} & 2 \frac{1}{2} \\
\mathrm{M} & 7 \\
\mathrm{~F} & 8\end{array}$ & $\begin{array}{l}2 \\
4 \\
6\end{array}$ & $\begin{array}{l}2,3,12, \mathrm{~W} 14 \\
1,12\end{array}$ & $\begin{array}{l}+ \\
+ \\
+\end{array}$ & $\begin{array}{l}3.13 \\
1.73 \\
2 \cdot 00\end{array}$ & $\begin{array}{l}2 \cdot 20(4), 2.33(8), 2 \cdot 33(12) \\
2 \cdot 06(2), 2 \cdot 00(6), 2 \cdot 40(12) \\
1 \cdot 47(2), 1 \cdot 33(4), 1.67(6), 2 \cdot 40(10)\end{array}$ & $\begin{array}{l}12 \\
12 \\
12\end{array}$ & $\begin{array}{l}+ \\
+ \\
+\end{array}$ & $\overline{-}$ & $\begin{array}{l}\text { Normal diet } \\
\text { Normal diet } \\
\text { Normal diet, repeat }\end{array}$ \\
\hline 25 & $M \quad 4 \frac{1}{2}$ & 3 & & + & $2 \cdot 13$ & $2 \cdot 06(2), 2 \cdot 80(4), 2 \cdot 60(6), 3 \cdot 20(10), 3 \cdot 13(12)$ & 13 & + & ++ & $\begin{array}{l}\text { biopsy } 15 \text { mo normal } \\
\text { Normal diet, repeat } \\
\text { biopsy } 10 \text { mo normal }\end{array}$ \\
\hline 26 & F 10 & 8 & $1, W 5, W 10$ & + & 1.73 & $1.86(2), 1.27(4), 1.67(6), 1.73(10)$ & 12 & + & - & $\begin{array}{l}\text { Normal diet, repeat } \\
\text { biopsy } 24 \text { mo normal }\end{array}$ \\
\hline 27 & M 6 & $4 \frac{1}{2}$ & $3,5,8$ & + & $2 \cdot 00$ & $2.33(2), 2.00(4), 1.67(6), 1.93(8), 2.26(10), 1.93(12)$ & 12 & + & ++ & $\begin{array}{l}\text { Normal diet, repeat } \\
\text { biopsy } 12 \text { mo normal }\end{array}$ \\
\hline 28 & F 5 & 2 & & & $2 \cdot 40$ & $2 \cdot 13(4), 2 \cdot 60(8), 2 \cdot 80(12)$ & 12 & + & - & $\begin{array}{l}\text { Normal diet, repeat } \\
\text { biopsy } 12 \text { mo normal }\end{array}$ \\
\hline $\begin{array}{l}29 \\
30 \\
31 \\
32 \\
33\end{array}$ & $\begin{array}{lc}F & 2 \frac{1}{2} \\
M & 6 \frac{1}{2} \\
M & 4 \frac{1}{2} \\
M & 10 \\
F & 2\end{array}$ & $\begin{array}{l}1 \\
1 \\
4 \\
2 \\
1 \frac{1}{2}\end{array}$ & $3,5,12$ & $\begin{array}{l}+ \\
+\end{array}$ & $\begin{array}{l}2 \cdot 40 \\
2 \cdot 13 \\
2 \cdot 13 \\
1.53 \\
3 \cdot 00\end{array}$ & $\begin{array}{l}2 \cdot 13(2), 2 \cdot 80(4), 1.13(6), 2.73(8), 2.33(10), 2.20(12) \\
2.00(2), 2.40(4), 1.93(8), 1.86(12) \\
2.40(2), 2 \cdot 26(4), 2.60(6), 2.80(8), 1.93(10), 2.40(12) \\
1.93(2), 2 \cdot 40(6), 2.66(10), 2 \cdot 73(12) \\
2.26(2), 3.00(6), 1.60(6), 1.73(10), 2.60(12)\end{array}$ & $\begin{array}{l}12 \\
12 \\
12 \\
12 \\
12\end{array}$ & $\begin{array}{l}+ \\
+ \\
+ \\
+ \\
+\end{array}$ & $\begin{array}{l}- \\
\overline{-} \\
\overline{-}\end{array}$ & $\begin{array}{l}\text { Normal diet } \\
\text { Normal diet } \\
\text { Normal diet } \\
\text { Normal diet } \\
\text { Normal diet, repeat } \\
\text { biopsy } 24 \text { monormal }\end{array}$ \\
\hline $\begin{array}{l}34 \\
35\end{array}$ & $\begin{array}{ll}\mathrm{M} & 3 \\
\mathbf{F} & 1_{1}^{\frac{1}{2}}\end{array}$ & $1^{\frac{1}{2}}$ & $1,11,7,8$ & $\stackrel{+}{+}$ & $\begin{array}{l}2 \cdot 93 \\
3 \cdot 26\end{array}$ & $\begin{array}{l}2 \cdot 86(2), 2 \cdot 93(4), 1 \cdot 86(8), 2 \cdot 46(10), 3 \cdot 13(12) \\
2 \cdot 00(2), 2 \cdot 06(6), 3 \cdot 13(8), 1 \cdot 47(10)\end{array}$ & 12 & $\begin{array}{l}+ \\
+\end{array}$ & $\bar{t}$ & $\begin{array}{l}\text { Normal diet } \\
\text { Normal diet }\end{array}$ \\
\hline
\end{tabular}

*Biopsy grading: + Normal-finger or leaf villi, epithelium normal. ++ Villi broadened-irregularity of epithelial cell heights, increased cells in lamina propria. +++

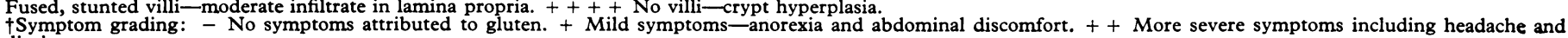
tSymptom
dizziness.

dizziness.

Conversion: SI to traditional units-Blood xylose: $1 \mathrm{mmol} / 1 \approx 15 \mathrm{mg} / 100 \mathrm{ml}$. 
concentration was followed in each case by the finding of a diagnostic enteropathy. We do not know, of course, whether or not abnormal intestinal histology could have been found before the fall in xylose absorption. The one-hour blood xylose test, used in this way, avoids the problem about the lower limit of normal for the test, ${ }^{1011}$ because it is a sustained fall in blood xylose, rather than an absolute value, that is the indication for biopsy.

In group 2 there were three children in whom a sudden drop in one-hour blood xylose occurred which was not confirmed. We therefore recommend that two abnormal results are obtained before ending the challenge with a biopsy.

One of our patients (case 18) was an adolescent outside the age range of the other children in this study. Although gluten administration caused a fall in the one-hour blood xylose concentration and some change in small-bowel histology the evidence was not sufficient to establish the diagnosis of coeliac disease beyond doubt although this remained a strong possibility. Therefore the normal biopsy result after a year on a normal diet was unexpected. These findings might be explained by "patchy lesions" in the mucosa or by a dose-dependent enteropathy such that even $20 \mathrm{~g}$ of gluten a day for eight weeks was insufficient to cause severe damage and such that the variable amount of gluten in a self-selected "normal" diet allowed recovery. ${ }^{12}$ Previous reports ${ }^{13}$ have suggested that during adolescence there may be a refractory period when the effects of gluten are unpredictable and any challenge studies in this age group must be interpreted with reservation.

This study clearly separated, with one exception, two distinct populations-group 1 and group 2. There was no clinical difference between the groups at the time of the challenge and patients in both groups exhibited mild symptoms during the challenge. The fact that six children in group 2 had symptoms but were shown to have normal post-challenge histology indicates that symptoms alone cannot be used as proof of gluten sensitivity. Symptoms were never severe enough to require termination of the challenge, but had they been abnormal biopsy findings would still have been required to make a firm diagnosis. The difference in the two populations is underlined by their HLA status. Of those children tested $82 \%$ in group 1 and $22 \%$ in group 2 were HLA-8. These figures are similar to published figures for a coeliac and a normal population respectively. ${ }^{14}$ It is not possible to state with certainty that the children in group 2 might not have developed mucosal damage if gluten administration had been continued beyond three months. It seems unlikely, however, since they seemed to be a different genetic population, follow-up showed them to be thriving on a normal diet, and biopsy specimens from eight of them taken a year or more after returning to a normal diet were normal. The factors that determined the speed of relapse in patients in group 1 are not known. Speed of relapse was not related to age, duration of gluten-free diet, pre-challenge small bowel histology, or HLA status.

In this study only half the 35 "coeliac" children could be proved to have coeliac disease. If these proportions exist elsewhere many children, diagnosed as having coeliac disease on inadequate grounds, are being subjected unnecessarily to a gluten-free diet. This study shows the usefulness of a standardised approach to gluten challenge and emphasises the importance of jejunal biopsy in the initial diagnosis of coeliac disease.

We are grateful to Professor C M Anderson for her advice and support during this study, and to the consultant paediatricians in the Midlands who referred some of their patients. We thank Dr A H Cameron for histological reporting and Energen Foods Ltd, who generously supplied gluten.

\section{References}

1 Coeliac Society, Gut, 1973, 14, 254.

2 McNeish, A S, and Anderson, C M, Clinics in Gastroenterology, 1974, 1, 127.

3 Meeuwisse, G W, Acta Paediatrica Scandinavica, 1970, 59, 461.

${ }^{4}$ Hamilton, J R, and McNeill, L K, Fournal of Paediatrics, 1972, 81, 885.

5 Young, W F, and Pringle, E M, Archives of Disease in Childhood, 1971, 46, 421 .

6 Packer, S, Rowlatt, R J, and Harries, J T, Archives of Disease in Childhood, $1974,49,819$.

${ }^{7}$ Rolles, C J, Anderson, C M, and McNeish, A S, Archives of Disease in Childhood, 1975, 50, 259.

${ }^{8}$ Rolles, C J, et al, Lancet, 1973, 2, 1043.

${ }^{9} \mathrm{McNeish}, \mathrm{A} \mathrm{S}$, et al, in Coeliac Disease: Proceedings of the Second International Symposium, ed W T J M Hekkens and A S Pena, p 300. Leiden, Stenfert Kroese, 1974.

10 Lamabadusuriya, S P, Packer, S, and Harries, J T, Archives of Disease in Childhood, 1975, 50, 34.

11 Rolles, C J, et al, Archives of Disease in Childhood, 1975, 50, 748.

12 Kendall, M J, Nutter, S, and Hawkins, C F, Lancet, 1972, 1, 667.

${ }^{13}$ Rolles, C J, and Kendall, M J, Lancet, 1973, 2, 381.

${ }^{14}$ McNeish, A S, Nelson, R, and Mackintosh, P, Lancet, 1973, 1, 668.
Metabolic Unit, Maudsley Hospital and Institute of Psychiatry, London SE5

G NIKITOPOULOU, MD, British Council scholar (now senior lecturer in physiology, University of Athens)

J L CRAMMER, MA, FRCPSYCH, senior lecturer in psychiatry, Institute of Psychiatry in each patient. While the daily temperature curve was essentially normal in manic phases, with pronounced 24-hour rhythm, during depression the daytime temperatures appeared disorganised, often falling during the morning instead of rising, and with suggestions of a 12-hour rhythm. It may be useful to look on manicdepressive illness as resulting from a desynchronisation of circadian rhythms and to compare the pharmacologies of temperature regulation and mood regulation in psychosis.

\section{Introduction}

In spite of many years' study no clear picture has emerged of any brain disorganisation that might underlie manic-depressive 